\title{
Ecology for the architecture of large hotel spaces
}

\author{
J. Jablonska \& E. Trocka-Leszczynska \\ Faculty of Architecture, Wroclaw University of Technology, Poland
}

\begin{abstract}
In contemporary hotels, the handling of large groups of customers requires specific architectural solutions in order to provide comfort, safety, hygiene and health protection. These solutions (later) affect the form and function of the whole building. Moreover, as the aspect of multifunctionality of large spaces increasingly gains importance, the choice of accurate materials and technologies, both in terms of general construction requirements and interior finishing, becomes more difficult. The presented research was focused on providing solutions for hotel's public spaces, such as: restaurants, cafés, banquet and conference halls, meeting rooms, exhibition spaces, lobbies, etc. Furthermore, the scope of the studies covered architectural acoustics, high visibility, optimal microclimate and materials' safety. It is only with such a full subject overview that we can talk about ecology in the design of large hotel spaces.

Keywords: large hotel spaces, ecology in architecture, ecological building materials.
\end{abstract}

\section{Introduction}

Large hotel spaces, i.e. lobbies, restaurants, recreation and wellness centers, are representative public areas, the trademarks of any hotel. The ambience, overall look, and architecture of such spaces interacts with users on the level of aesthetics, as well as through the sense of sound, smell and touch. At the same time, it is crucial to note that as various factors ensure the comfort and safety of guests, they also directly affect a user's health. The latter aspect, strictly connected with ecology, is understood not only in terms of solutions based on renewable energy sources or high- and low-tech technology, but also through appropriate lightening, 
ventilation, use of building's surroundings and localization, reduction of noise pollution, materials used for interior finishing and many more.

As the discussed hotel areas are characterized by extensive tracts and large cubatures, it is important to design adequate light scattering on wall-and-ceilingsurfaces, as well as to use acoustic solutions enabling the dimming of noise, good audibility of speech, reduction of reverberation time and prevention of echo occurrence. Architects focused on complying with the above mentioned standards, aesthetics and fire safety requirements, often forget about the ecological aspect of chosen materials. Environmental friendliness of a product should be considered both in the process of obtaining raw materials, production, transportation, and effect on people, as well as during usage and finally degradation or demolition [1]. Another aspect directly connected with ecology is the possibility of building with recycled materials and later processing the products after their dismantling.

Users of large hotel spaces are exposed to various chemical and biological agents, present on the inside as well as on the outside of the building. Hazardous compounds are released from building and finishing materials, emitted from the natural environment, as well as from detergents, disinfectants, furniture preservatives, paint, varnish, etc. (Figure 1) Moreover, such compounds may derive from clothing, or be released by other users, e.g. exhaled carbon dioxide, microbes, viruses, bacteria and fungi on human skin. Hazardous to health, and partly to the environment, are also noise and ionizing radiation. [2, 3] Chemical molecules and biological threats, deposited along with dust on all kinds of surfaces, have an especially adverse effect in longer periods of time. Civilization diseases, cancer and an increasing percentage of allergies (according to statistical data over $50 \%$ of Poles are currently considered allergic to the so-called common allergens, while approx. 17 million Europeans suffer from food allergies) [4], as well as prognosis indicating an ongoing rise of such phenomena, make the caring for the ecology of space a necessity rather than a fashion.
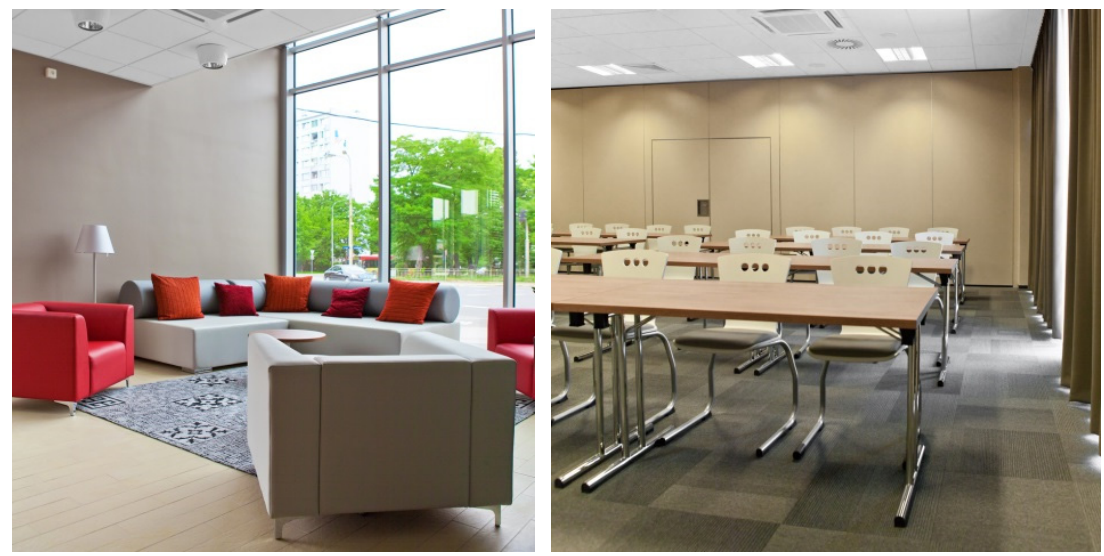

Figure 1: "Campanille" hotel in Wrocław - usage of different building and finishing materials. (Photos: Lech Kwartowicz.) 


\section{Methodology}

In the light of the issues outlined above, the paper is dedicated to the architectural design of large hotel spaces, in regard to the ecological aspect of creating a microclimate and used materials. Presented research is considered to be of a detailed and theoretically-practical character. The limitation of the study scope to large contemporary hotel spaces was directed by their similar requirements in regard to: microclimate, acoustics and safety. Notably, material solutions are the key focus of the paper, as their choice is directly dependant on the architect.

The paper discusses solutions which are, or could be, utilized in hotels in Poland. In terms of law and regulations, the focus is mainly on national documents, due to their high restrictiveness among European legislation and the topic localization. Both Polish and foreign literature has been analyzed, the choice of which is referenced in the paper. An important part of the study was conducting a series of field examinations of facilities both in Poland and abroad. It needs to be emphasized that a discussion of individual cases has been abandoned in order to formulate a more universal description. Conclusively, the following research methods have been applied: analysis, comparative and critical analysis, and synthesis.

\section{Environment}

Microclimate is the impact of all physical elements on the heat balance of a human body. It encompasses the following aspects: temperature, humidity, air purity, movement and ionization, quality of acoustic environment (including noise), intensity of electric and electromagnetic fields, interior lighting and color of its components, the degree of radiation, interaction of flora and fauna, user-exhaled carbon dioxide and presence of bacteria and viruses. It needs to be noted that the perception of these parameters, e.g. temperature, is partly dependant on the psycho-physical condition of an individual present in the room, and partly on the individual's activity and characteristics. [2]

The appropriate level of humidity for a human being in unheated rooms equals $40-60 \%$ and $40-45 \%$ for heated rooms. These standards are based upon an overall production of moisture, as well as characteristics of building materials from which building envelopes are constructed, presence of people, animals and plants. Both humidity excess and humidity deficit are considered health hazards. The prior may lead to the development of mold and mildew and therefore to the release of poisonous toxins, while the latter to diseases associated with mucosal dryness (e.g. dryness of oral mucosa). Moreover, in dry rooms dust residues accumulate as a result of surface electrification [2]. In the aspect of optimal air exchange, it is vital to avoid drafts and sudden gusts of wind as they expose the body to a sudden temperature drop.

Adequately designed acoustic field fosters clarity and intelligibility of speech, reduction of overall and impact noise, facilitates spatial orientation, and, finally, users' safety. Among the factors ensuring a comfortable acoustic microclimate are the following: ambient noise level, noise frequency in a room (for example, 
rumbling and roaring installation noises are perceived as unfavorable), and adequately selected type of music. Another element worth mentioning is the aspect of vibration in hotels (associated with the work of elevators, air conditioning, electrical transformers etc.). In large interiors inner acoustic insulation is vital, yet insufficient. A variety of sounds are formed within rooms and are enhanced due to the large cubatures where materials reflecting acoustic waves are eagerly used (walls, floors, ceilings, glazings). Additionally, frequently, the echo phenomenon can also be observed. According to the Polish Norm PN-87/B-02151/02 [5], the acceptable noise level, i.e. noise created by all external and internal sources during daytime (nighttime values being not specified), equals $40 \mathrm{~dB}$ for conference rooms, and $50 \mathrm{~dB}$ for cafés and restaurants. The described parameters call for special attention in the aspect of adequate material solutions. [5]

In the case of adequate lightning design, both the insufficiency of light, its excessive intensity and brightness may pose a hazard to users. Especially dangerous are high contrasts and glare effects. Beneficial on the other hand, are gradual intensifications of light and appropriate selection of light sources, depending on the area's exploitation form and function [2]. The effect can be weakened or intensified through the choice of material, e.g. bright surfaces with a delicate structure foster light scattering, while thick, dark fabrics possess a light absorbing capacity.

In large interiors it is crucial to pay attention to the selection of solutions reducing the risk of accumulation or development of previously mentioned harmful elements (e.g. mites, fungi, mold, radon), among others, in dust. Dust deposition is conducted by smooth, glossed furniture surfaces, plastics, and monitors, i.e. charged surfaces. Therefore, dust will more easily accumulate around heating devices, their housing, around exhausts of air conditioning and ventilation systems, as well as housing of electrical cables. Unfavorable are also all types of cavities, e.g. sewages, floor convectors, separation joints $[2,6]$. Moreover, reducing the negative effect of electric field on users can be fostered by shortening the working time of installations and equipment, while the reduction in power consumption further enhances ecological friendliness of the facility, not to mention the reduction of operating costs.

Another very important factor is the exposure of buildings' users to ionizing radiation. Direct gamma radiation may be produced by certain building materials, such as those containing blast furnace glass, concrete, as well as selected ceramic and gypsum products [2]. Furthermore, as Korzeniowski-Rejmer [6] notes, isotopes like radon -220 and radon -222 are present in buildings as a result of a dissolution of uranium - 238 and thorium - 232, naturally present in inanimate nature. Radon may accumulate not only in the underground parts of the building, but also, as gas, it is emitted in the air directly from rocks and soil. The authors recommend a series of actions enabling the reduction of negative ionizing radiation effect, including: soil examination (its structure and type), evaluation of underground infrastructure, examination of construction products, air-tight building, application of adequate isolation materials, ventilation of the underground structure and rooms within the facility by applying appropriate pressure differentiation [6]. 
Each of these parameters can be controlled by architects and engineers at the stage of planning, building or interior design. The simple matrices of such connections have been presented in the following table (see Table 1).

Table 1: Matrix of connections for selected microclimate elements and architectural output.

\begin{tabular}{|l|l|l|l|}
\hline & $\begin{array}{l}\text { Microclimate } \\
\text { element }\end{array}$ & \multicolumn{1}{|c|}{ Environmental impact } & \multicolumn{1}{|c|}{ Connection to architecture } \\
\hline 1 & Humidity & $\begin{array}{l}\text { human health, flora and fauna } \\
\text { conditions, biological hazards }\end{array}$ & $\begin{array}{l}\text { building materials, insulation, } \\
\text { ventilation }\end{array}$ \\
\hline 2 & $\begin{array}{l}\text { Acoustical } \\
\text { field and } \\
\text { vibrations }\end{array}$ & $\begin{array}{l}\text { human health, flora and fauna } \\
\text { conditions, }\end{array}$ & $\begin{array}{l}\text { building materials, insulation, } \\
\text { finishing materials, appliances, } \\
\text { architectural material distribution }\end{array}$ \\
\hline 3 & Airflow & $\begin{array}{l}\text { human health, flora and fauna } \\
\text { conditions, }\end{array}$ & $\begin{array}{l}\text { architectural design of building } \\
\text { compartments and openings, } \\
\text { ventilation, heating devices }\end{array}$ \\
\hline 4 & Light & $\begin{array}{l}\text { human health, flora and fauna } \\
\text { conditions, usable hazards }\end{array}$ & $\begin{array}{l}\text { architectural design of building } \\
\text { compartments and openings, } \\
\text { materials, interior design } \\
\text { interior design, finishing material } \\
\text { types and their distribution, air } \\
\text { circulation, ventilation, heating } \\
\text { devices }\end{array}$ \\
\hline 5 & Dust & $\begin{array}{l}\text { human health, flora and fauna } \\
\text { conditions, biological hazards }\end{array}$ & $\begin{array}{l}\text { architectural form and foundation } \\
\text { design, ventilation }\end{array}$ \\
\hline 6 & Radiation & $\begin{array}{l}\text { human health, flora and fauna } \\
\text { conditions }\end{array}$ & \\
\hline
\end{tabular}

\section{Building materials and construction minerals}

Based on their acoustic characteristics, materials can be divided into the following: isolating, reflecting, scattering, absorbing, scattering/absorbing, and reflecting/ absorbing, while their properties are connected with density and structure (level of porosity). In hotels reflective raw materials can be found primarily in floors, which is due to their utilization and maintenance in cleanliness. Walls and ceilings are designed using the combination of absorbing, reflecting and scattering solutions, through which an adequate level of "mixing", volume, and "softness" of the acoustic field can be achieved. This is paired with the prevention of the phenomenon of excessive prolongation of reverberation time, multiplication of impact noise, unintelligible speech and echo. At the same time, the level of light reflection from finishing materials is closely associated with the colour of the material's surface, while the possibility of light scattering, with the material's texture and level of porosity (Figure 2).

Another classification formulated by Zielonko-Jung and Marchwiński [1] divides construction materials based on the amount of energy consumed from the 
moment of their production to the delivery to the construction site. The authors connect these properties with the concept of primary energy input (PEI), which determines the amount of energy for obtaining raw materials, production of the material, its transportation and installation. The discussed typology distinguishes: low, intermediate and high energy materials. The first group encompasses the following: sand, wood, concrete; the second: plasterboard, bricks, glass, mineral wool; while the third: plastic and steal. It is also essential to determine the share of renewable and non-renewable energy used to produce a material. Another variable is the so-called recurring embodied energy, i.e. energy associated with the use of a specific material, its maintenance, repair and eventual replacement. The last parameter is related to the duration of building's utilization, durability and quality of the material. [1]
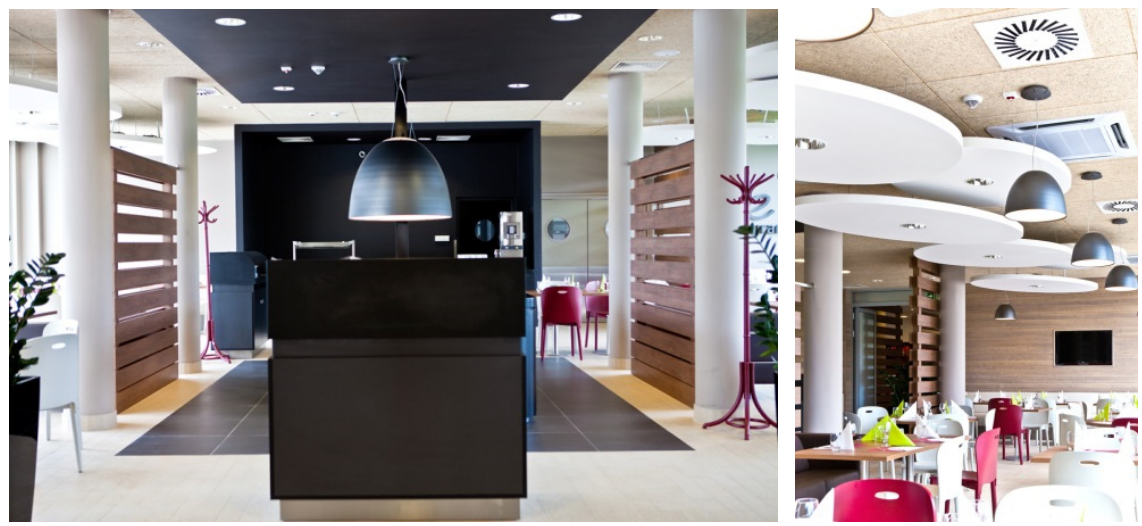

Figure 2: "Campanille" hotel in Wrocław - distribution of materials with different properties. (Photos: Lech Kwartowicz.)

Another crucial aspect taken into account is the direct impact of molecules released by building materials during the time of their use, or at the time of a fire, which further affects human health and the state of the environment. In Poland, the limitations and acceptable norms of hazardous substances contained in building materials are regulated by "The Ordinance of the Ministry of Health and Social Care from 12 March 1996 on permissible concentrations and intensities of health-hazardous factors emitted by building materials, devices, and accessories in spaces designed to accommodate people" [3].

\section{Examples of solutions}

Wood is a natural material that reflects sound and, while referring to the tradition, creates an impression of elegance and comfort. As such, it is willingly and commonly used in the hotel industry. If applied in the form of thin cladding panels mounted on the inside walls of spacer constructions, it may be used as a lowfrequency-absorber. This is due to plate vibrations induced by an increase of 
acoustic pressure [7]. Being available in many varieties, one can decide on a light to dark surface with a variable of growth-rings and other decorative patterns. Wood, as a natural renewable raw material [2], possesses particular significance in ecological solutions. The reduced amount of energy input in its processing, resulted in wood being classified as a low energy material in the Zielonko-Jung and Marchwiński classification [1]. Natural waste produced in the process of, either, the production of building elements, or the interior and furniture design solutions, may be later used in the production of other materials, such as plywood, particle and fibreboards (recycling), or as biomass fuel. Due to the relatively low resistance to biological hazards and fire, wood is often subjected to chemical impregnation and varnishing with health hazardous preparations. However, as a result of development of the ecological trend, also here a return to natural resources can be observed, with the introduction of linseed oil and pastes based on beeswax. As a result of industrialization, new and often highly processed products were introduced next to natural wood. Often in the discussed products wood remains the raw material, such as in plywood, medium-density fibreboard (MDF), oriented strand board (OSB), laminate flooring, products are all commonly applied in interior finishing or in designing furniture. In the discussed group, glued laminated timber is used as a construction material $[1,2]$.

Stone is another willingly used material in hotel interiors, especially those of higher standard. This natural and durable material, providing good light and acoustic wave reflection, is used in floors, walls and in certain equipment pieces, such as reception desks, benches, sanitary wares and sculptures. In SPA resorts, as well as by swimming pools, the heat accumulation capacity of stone is utilized [1]. Stone as a construction material is characterized by a relatively simple production process, however, due to its significant weight, the material is energyintensive in transportation and may additionally require strengthened construction, for example when installed as wall cladding.

Among products encompassing raw materials one should also mention: ceramics, concrete, glass and gypsum. Ceramics is a clay-based material, widely utilized in the construction industry in the form of solid, porous brick, blocks and cobbles, as well as panels, for example, sun shades. Due to their heavy weight, solid products, such as brick walls, may be used for indoor-soundproofing, as well as for reflecting acoustic waves, including those with lower frequencies [7].

Concrete is a cool and smooth material utilized not only in construction but also in interior finishing. In the aspect of acoustic parameters, concrete isolates noise from the outside including low frequency sounds. Moreover, its mass prevents it from vibrating. Concrete, i.e. textured and rough concrete blocks, the so called architectural concrete which absorbs intermediate and high sound frequencies, while scattering the reflected sound waves at the same time, is also used in interior decorating and finishing. Although concrete has been primarily used as a constructive material, its properties are being continually improved (high strength, high performance, waterproof, etc) $[1,2,7]$.

Glass, though a brittle material, is often used in the construction industry for all kinds of transparent and translucent, external and internal partitions. Despite being not biodegradable, through relatively easy disposal - melting - it may be 
considered an ecological material. Moreover, the types of glass used today allow for a reduction of the interior overheating risk. Within the scope of the study, the following types of class call for attention: low-carbon, bi-functional with solarcontrol coating and sun protection $[1,2]$.

Another popular material utilized in the building industry is plaster. Plaster is a mixture of calcium hydroxide, gypsum, cement, sand and other admixtures, and is commonly used as a top coating of large surfaces, walls and ceilings. Plastered prepared partition walls will reflect sound, and after coating with a bright paint, they will also reflect and scatter light. If plaster coated surfaces are of less than 1$2 \mathrm{~cm}$, plaster may vibrate, thus absorbing acoustic energy waves with low frequencies. When coating is given structure, it will act as a diffuser, dispersing sound. In terms of creating a microclimatic interior, an important property of the discussed material should be mentioned, that is, open pores facilitating the diffusion of water vapor. Additionally, it is worth noting that plaster is recyclable. Mixes with resins result in a tight material, less favorable in matters of health. Such products may also release hazardous molecules - isocyanate (present in polyurethanes, dangerous to the eye mucosa, gastrointestinal tract and respiratory tract), as well as chlorides. [2, 8] However in Poland, the presence of chlorophenols, including pentachlorophenol, in construction materials used on the interior is illegal, while carbon tetrachloride in building materials is fully prohibited $[2,3,7]$.

The use of textiles is often a solution for reducing the reverberation time in large hotel spaces. Furthermore, textiles give an interior a character and, through a possibility of frequent replacements, they may create an effect of a remodeled space. The following fabrics are considered absorbing materials: furniture upholstery, selected ceiling panels, carpets, drapes, draperies, etc. Interestingly, the discussed materials also help in reducing echo, facilitate a better clarity of speech, as well as an overall and impact noise reduction. However, a surplus of absorbing materials will result in excessive noise reduction and perception of "dead" or "dry" sound [7].

Textiles of plant (e.g. linen) or animal (e.g. sheep wool, camel hair) origin, although natural, may be dangerous for people with allergies. In their case, synthetic fibers are safer (e.g. polyamide, polypropylene, polyacryl, polyester), as fungi and mold do not grow on them. Unfortunately, also the above mentioned fabrics are subjected to chemical detergents, which, on the one hand, improve their resistance to dirt, and, on the other, reduce their health safety. Moreover, synthetic materials may retain static electricity, leading to accidental discharges, while, for example, carpets are fitted with a supporting layer, possibly containing other hazardous substances and glues. In case of all kinds of seats, upholsteries, etc. it is crucial to use "breathable" fabrics and upholstery foams of an airy, porous structure. This will lead to diminishing the risk of dampness and prevent the development of biological and toxic hazards in furniture $[2,7]$.

Mineral wool (produced in the recycling process) and, sporadically, sheep wool are used as acoustic-and-heat-isolating materials. Among recycled materials one should also mention fiberglass and PET-byproducts discs, e.g. currently available in Poland IZOPET-R. At the moment, the latter is utilized only as a drainage plate, 
because of the lack of an appropriate license allowing it to be marketed as thermal insulation [9]. However unfavorable, all kinds of polystyrenes and styrodurs, continue to be used, due to their low cost and durability to biodegradation $[1,2]$. Bitumens and PVC foils, byproducts of rubber recycling, are counted among waterproof materials (isolating the exterior of a building). The earlier mentioned Health Ministry guidelines, prohibit the usage of materials deriving from coal processing, i.e. tar or binders, in interiors, as they are considered hazardous to human health $[1,3]$.

Plasterboards, commonly used as light partition walls in interiors, wall, ceiling and installation cladding, possess moisture-and-fire-fighting parameters. These elements may significantly influence room-acoustics through the applied construction system, including an installation of up to two plasterboards on a steel frame. Such an arrangement causes plasterboards to vibrate, resulting in an absorption of low frequencies. An advantage of the discussed product is its recyclable origin, as plasterboards are created from gypsum and paper deriving from secondary product, i.e. waste paper. Plasterboards further foster the diffusion of water vapor, reducing the threat of mold and fungi growth.

Solid plaster and plasterboard walls require an additional surface finishing. However, all materials such as paints, glues, varnishes, wood-based materials, isolations and preservatives may release volatile chemicals, such as formaldehyde, turpentine, and benzene to the atmosphere. In Poland, benzene, in an unbound form, has been approved for usage in building materials in the concentration not exceeding $0.1 \%$ of the material's total mass [3].

All basic paint ingredients, from pigments, often obtained from heavy metals (it needs to be noted that in Poland lead cannot be used in building materials), through chemical dissolvants, to synthetic admixtures, may be hazardous to health. An example of health disadvantageous, and yet common product from the discussed category, are dispersion paints based on synthetic resins. Similar varnishes contain dissolvents and synthetic admixtures including the earlier mentioned benzene and formaldehyde. Much safer are products based on natural resins and aqua-solvents. In Poland the amount of chlorinated hydrocarbons (excluding carbon tetrachloride) dissolvent in building materials, may not exceed $5 \%$ of the overall mass, while linden, as a component of impregnating and varnishing articles, is completely prohibited in building materials used in interiors. $[2,3]$. Finally, epoxy and polyurethane resins used in manufacturing selected floor coatings, sealants and preservatives may release already mentioned isocyanate or bisphenol-a and epichlorhydrin (present in epoxides) $[8,10]$.

Wallpaper, tailored to the character of the interior, is another common method of wall finishing. This product is available in a wide range of varieties and consist of two layers, namely, the construction layer with the following warps: synthetic (fiseline), fabric, fiberglass, paper, and the outer, decorative, layer, out of: paper, fabric, vinyl (flat or expanded), silk, wool, or cork. Whereas natural solutions foster the diffusion of water vapor and synthetic ones block it, glues used for installations will act according to the same principle [2].

Various plastics are also utilized in contemporary construction industry and interior finishing. Reservations are brought about already by their production 
process. Having been classified, according to Zielonko-Jung and Marchwiński to the high energy group, plastics are particularly dangerous in the event of a fire (e.g. PVC-type plastics release toxic dioxins [11]). Additionally, as they are an unsustainable material, they bring about a need of frequent component replacement. Plastics may also release toxic molecules during exploitation and are not subject to biodegradation. However, plastic is often being recycled. Unfortunately, plastic window frames, cheaper by far from their wooden equivalents, are becoming increasingly popular in Poland, even though, their production calls for a substantial, up to 6-times greater, energy consumption. Moreover, during their manufacturing process, harmful substances, such as lead and cadmium, are released to the atmosphere. In face of this data, wooden frames prove to be a significantly more advantageous solution, as not only do they foster a better inner microclimate, but also enable a release of excessive moisture from the room [2] (Figure 3).
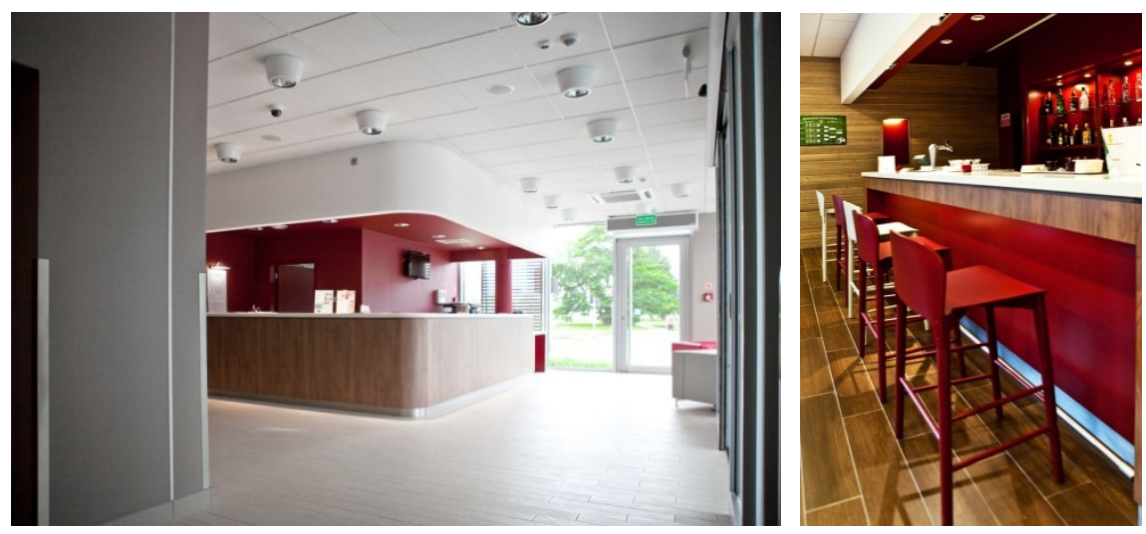

Figure 3: Hotel "Campanille" in Wrocław - an example of a different use of finishing materials in terms of colour, texture and patterns. (Photos: Lech Kwartowicz.)

Metals such as steel and aluminum are used not only as building materials (structural, reinforcement of concrete structures), but also finishing ones for the production of furniture, railings, etc. Furthermore, the discussed materials are commonly used as wall and housing column claddings, installed on auxiliary and standoff structures. In this system, metal plates fall into the so-called "diaphragm movements" what results in absorption of low frequency sound waves. Metals belong to the high energy group according to Zielonko-Jung and Marchwiński [1, $2,7]$.

\section{Conclusion}

As a summary of the discussion a table has been formulated (see Table 2), presenting the general and ecological qualities of selected material examples, with their interior design evaluation. 
Table 2: $\quad$ Parameters of selected materials.

\begin{tabular}{|c|c|c|c|c|c|}
\hline No. & Material & Ecological type/type & $\begin{array}{l}\text { Ecological } \\
\text { properties }\end{array}$ & $\begin{array}{l}\text { Acoustical } \\
\text { properties }\end{array}$ & $\begin{array}{l}\text { Interior } \\
\text { design } \\
\text { qualities }\end{array}$ \\
\hline 1 & wood & natural/homogeneous & very high & reflective & very good \\
\hline 2 & $\begin{array}{l}\text { processed wood } \\
\text { products (i.e. } \\
\text { plywood) }\end{array}$ & mixed/compound & medium & reflective & $\begin{array}{l}\text { very good or } \\
\text { standard }\end{array}$ \\
\hline 3 & stone & natural/homogeneous & very high & reflective & very good \\
\hline 4 & $\begin{array}{l}\text { ceramics (i.e. } \\
\text { brick) }\end{array}$ & natural/compound & high & reflective & very good \\
\hline 5 & concrete & $\begin{array}{l}\text { natural/natural and } \\
\text { artificial/compound }\end{array}$ & high & reflective & $\begin{array}{l}\text { very good or } \\
\text { standard }\end{array}$ \\
\hline 6 & glass & $\begin{array}{l}\text { natural/natural and } \\
\text { artificial/compound }\end{array}$ & high & reflective & $\begin{array}{l}\text { very good or } \\
\text { standard }\end{array}$ \\
\hline 7 & plaster & $\begin{array}{l}\text { natural/natural and } \\
\text { artificial/compound }\end{array}$ & $\begin{array}{l}\text { from high to } \\
\text { medium }\end{array}$ & $\begin{array}{l}\text { reflective, } \\
\text { diffusive }\end{array}$ & standard \\
\hline 8 & plaster boards & $\begin{array}{l}\text { natural/natural and } \\
\text { artificial/compound }\end{array}$ & $\begin{array}{l}\text { from high to } \\
\text { medium }\end{array}$ & $\begin{array}{l}\text { partially } \\
\text { reflective } \\
\text { and } \\
\text { absorbent }\end{array}$ & standard \\
\hline 9 & $\begin{array}{l}\text { textile based on } \\
\text { natural origin }\end{array}$ & $\begin{array}{l}\text { natural/natural and } \\
\text { artificial/ } \\
\text { homogeneous } \\
\text { /compound }\end{array}$ & $\begin{array}{l}\text { from high to } \\
\text { low }\end{array}$ & absorbent & $\begin{array}{l}\text { from very } \\
\text { good to low }\end{array}$ \\
\hline 10 & wallpapers & $\begin{array}{l}\text { natural/natural and } \\
\text { artificial/ } \\
\text { homogeneous } \\
\text { /compound }\end{array}$ & $\begin{array}{l}\text { from high to } \\
\text { low }\end{array}$ & absorbent & $\begin{array}{l}\text { from very } \\
\text { good to low }\end{array}$ \\
\hline
\end{tabular}

Contemporary hotels, and especially their representative spaces, should be designed within the ecological scope. Reducing the impact of hazardous factors, i.e. ionizing radiation, electromagnetic field, toxic chemicals, biological hazards, noise, and overheating, on human beings is as important, as compliance with the construction law and safety of users. Due to the fact that the hazards associated with inadequate usage of building materials are not fully examined (e.g. risks associated with the usage of plastics), while the industry is subject to continuous development and new products continue to be introduced to the market, there is a need for broader, also interdisciplinary, research. Especially crucial is the dissemination of the existing knowledge among architects, involved in both theory and practice, as profit-seeking manufactures exploit the situation by stressing primarily utilitarian and aesthetical qualities of their products.

Moreover, an architect, as a project coordinator, has influence on the implemented installations, airing methods, lightening and noise pollution. The raise of awareness in the responsibility of the ecology of implemented solutions, and through it the impact on the health of users, will lead to a beneficial raise in the quality of space not only in hotels. 


\section{Acknowledgement}

Photos reprinted with the permission of the author.

\section{References}

[1] Zielonko-Jung K., Marchwiński J., Współczesna architektura proekologiczna, Wydawnictwo Naukowe PWN, Warsaw 2012, pp. 18-31.

[2] Nowakowski P., Ergonomiczne projektowanie strefy wypoczynkowej mieszkania, Ph.D. Thesis, Supervisor: Charytonowicz J., Wrocław 2000, pp. 187-216.

[3] Zarządzenie Ministra Zdrowia i Opieki Społecznej z dnia 12 marca 1996 r. w sprawie dopuszczalnych stężeń i natężeń czynników szkodliwych dla zdrowia, wydzielanych przez materiały budowlane, urządzenia i elementy wyposażenia w pomieszczeniach przeznaczonych na pobyt ludzi (The Ordinance of the Ministry of Health and Social Care from 12 March 1996 on permissible concentrations and intensities of health-hazardous factors emitted by building materials, devices, and accessories in spaces designed to accommodate people). M.P. $1996 \mathrm{nr} 19$ poz. 231.

[4] Statystyka alergii w Polsce i na świecie, 2014-08-20, Web: http://www.pokonacalergie.org/statystyka-alergii-w-polsce-i-naswiecie/184/, accessed: 2014-04-18.

[5] Polska Norma. Akustyka budowlana. Ochrona przed hałasem pomieszczeń w budynkach. Dopuszczalne wartości poziomu dźwięku w pomieszczeniach (Polish Norm. Building acoustics. Noise protection facilities in buildings. The permissible sound level values on the premises). PN-87/B-02151/02.

[6] Korzeniowska-Rejmer E., Radon w gruncie i techniki redukcji jego stężenia w obiektach budowlanych, in: "Czasopismo Techniczne Politechniki Śląskiej", 1-Ś/2008, pp. 73-88.

[7] McCandless D., Concert Halls. Specifying Sound for Performance, reprinted with permission from "The Construction Specifier", April 1999, Web: www.jeacoustics.com/library/pdf/ConSpec_Apr90_Concert Halls.pdf, accessed: 2013-04-25.

[8] Isocyanates, after: National Institute for Occupational Safety and Health Division of Applied Research and Technology, 2014-04-23, Web: http://www.cdc.gov/niosh/topics/isocyanates/, accessed 2014-05-02.

[9] Web: http://www.promos.com.pl/izopet/, accessed 2013-04-25.

[10] Posadzki przemysłowe, Web: http://www.innovare.waw.pl/posadzki zywiczne_przemyslowe.html, accessed: 2014-05-03.

[11] Gościniak M., Plastik plastikowi nierówny, in: "Ulica ekologiczna" 201211-20, Web: http://ulicaekologiczna.pl/zdrowy-styl-zycia/plastikplastikowi-nierowny/, accessed: 2014-05-03. 